Article

\title{
Investors' Delight? Climate Risk in Stock Valuation during COVID-19 and Beyond
}

\author{
Andrea Jacob ${ }^{1}$ (1) and Martin Nerlinger ${ }^{2, *}$ \\ 1 Chair of Finance and Banking, University of Augsburg, Universitaetsstr. 16, 86159 Augsburg, Germany; \\ andrea.jacob@wiwi.uni-augsburg.de \\ 2 School of Finance, University of St. Gallen, Unterer Graben 21, 9000 St. Gallen, Switzerland \\ * Correspondence: martin.nerlinger@unisg.ch; Tel.: +41-712247031
}

Citation: Jacob, A.; Nerlinger, M. Investors' Delight? Climate Risk in Stock Valuation during COVID-19 and Beyond. Sustainability 2021, 13, 12182. https://doi.org/10.3390/ su132112182

Academic Editor: David K. Ding

Received: 13 September 2021

Accepted: 31 October 2021

Published: 4 November 2021

Publisher's Note: MDPI stays neutral with regard to jurisdictional claims in published maps and institutional affiliations.

Copyright: (c) 2021 by the authors. Licensee MDPI, Basel, Switzerland. This article is an open access article distributed under the terms and conditions of the Creative Commons Attribution (CC BY) license (https:// creativecommons.org/licenses/by/ $4.0 /)$.

\begin{abstract}
We use the COVID-19 pandemic period in 2020 as an exogenous shock event to assess in how far climate risks measured by carbon exposure have entered and established themselves in the valuation of global stocks. In addition to descriptive analyses, we conduct cross-sectional panel regressions to assess the influence of carbon intensity levels on return and risk characteristics during and after the shock period. Furthermore, a difference-in-differences model setup allows us to infer whether these influences were significantly different when comparing pre-shock, shock, and post-shock periods. We find that carbon intensity affected returns significantly and negatively during a time of high uncertainty. In fact, high-emitting stocks suffered significantly more compared to the pre-crisis period. However, they could make up for their additional losses in the recovery period. In line with their high-risk exposure towards stranded assets and climate policy uncertainty, carbon-intensive stocks face higher risk levels in more stable economic times, thus justifying a carbon premium.
\end{abstract}

Keywords: climate risk; COVID-19; investment decisions; equity returns

JEL Classification: G01; G11; G12; Q54

\section{Introduction}

Making decisions under uncertainty is one of the indispensable tasks of financial market participants. Dealing with uncertainty involves the proper management of risk. In recent times, investors have had to learn how to cope with a new impending risk source: climate change. Environmental-related risks such as extreme weather events, climate action failure, and human-made environmental damage rank among the top risks by likelihood and impact in the World Economic Forum's Global Risks Report 2021 [1]. Apart from physical risks, technological innovations and climate policy measures targeted towards reaching a low-carbon economy may result in stranded assets [2]. Governments worldwide are committed towards combatting climate change by reducing carbon emissions (see, e.g., the Paris Agreement of 2015) and clients increasingly demand sustainable investments [3]. Hence, climate risks have evolved as real investment risks for financial assets with an expected reallocation of capital towards sustainable investments [4,5].

Even though investors recognize that climate risks have financial impacts on their portfolios, the financial industry still has to elaborate on how to incorporate these risks in their investment practices [5]. When one trusts in the reliability of the financial market, asset prices should mirror all available information [6]. Therefore, a re-evaluation of assets is essential for managing climate risks. Based on a fundamental stock analysis, the value of carbon-intensive stocks should be impacted by their high exposure towards stranded assets, technological changes, and potential carbon emission mitigation plans such as carbon pricing or carbon taxes [7-10]. 
Financial market participants drastically revise their expectations on how to evaluate assets when extreme situations occur. Such re-evaluations eventually become apparent in a consequential fall or rise in asset prices. The economic downturn at the beginning of the COVID-19 pandemic in early 2020 constitutes such an extreme tail-risk event that has induced investors to a re-evaluation of their holdings leading to a dramatic drop in stock market values worldwide (e.g., [11-14]). We use this exogenous shock to assess how far carbon emissions have entered the valuation process of equity prices. Such an exogenous shock that has arisen unexpectedly allows us to analyze investors' preferences towards carbon-related characteristics while holding carbon intensity levels constant. Since the awareness of climate risk has intensified in recent years, we are now at a point in time where there are sufficient and adequate data to test implications for stock analyses. An unexpected shock, and especially the incomparable COVID-19 event, either makes investors lose sight of their environmental awareness or confirm their commitment. The recent pandemic thus provides a first opportunity to derive implications of the integration of climate-related aspects on the stock valuation process. In this way, we gain deeper insights into how carbon intensity establishes itself as a fundamental characteristic in stock analysis during and after a period of heightened uncertainty and fear.

In the literature, the role of carbon emissions in stock valuation is studied in different setups. Matsumura, Prakash, and Vera-Munõz [15] find a negative relation between carbon emissions and firm value and an additional penalty for nondisclosure of emissions. Chava [16] finds that firms with climate change concerns have to bear higher costs of equity capital and debt capital. In contrast, Delmas, Nairn-Birch, and Lim [17] and Busch et al. [18] both come to the conclusion that higher carbon emissions increase at least short-term performance while disagreeing on their impact on long-term performance. Recent studies focus on a risk premium for holding emissions-intensive stocks. Hsu, Li, and Tsou [19] attribute the existence of a pollution premium to environmental policy uncertainty. Bolton and Kacperczyk [7] find a carbon premium that is related to the level of and to changes in carbon emissions. The existence of a carbon premium is consistent with the notion that carbon-intensive stocks face higher tail risks associated with climate policy uncertainty [20]. Furthermore, theoretical studies indicate that carbon-intensive assets underperform in response to unexpected positive changes in environmental preferences, even when in equilibrium they should outperform the market [21,22].

Studies on the relationship between stock characteristics, returns, and resilience during crisis periods constitute another relevant strand of literature for our study. For example, Duchin, Ozbas, and Sensoy [23] find that low cash reserves and high net short-term debt led to a greater decline of corporate investment during the Global Financial Crisis (GFC). For the COVID-19 period, markets valued firms lower when they were more exposed to international trade, higher corporate debt, and lower cash holdings [24]. Shields, El Zein, and Brunet [25] show that sustainable stocks have lower volatility than less sustainable stocks during the COVID-19 period using a GARCH framework. In addition, socially responsible and sustainable stocks measured by environmental, social, and governance criteria (ESG) have turned out to provide more resilience during the GFC [26] and the COVID-19 shock $[27,28]$. Other shocks, such as the global climate strike or U.S. elections, lead to a change in firm valuations due to increased public interest, uncertainty in expectations of regulation, and the devaluation of longer-term earnings forecasts for carbon-intensive firms $[29,30]$.

The reasons why markets and investors impose higher valuations on more sustainable stocks during crisis periods are manifold. Investors have higher trust in sustainable firms [26], are more patient, i.e., more loyal [28,31], perceive sustainability as a necessity rather than a luxury good [32], and have higher preferences for sustainable funds $[33,34]$. Additionally, studies prove the risk mitigation potential of sustainable stock traits (e.g., [35-37]).

This study analyzes how climate risk enters the re-evaluation considerations of investors in times of high uncertainty and beyond. Climate risk exposure is best approx- 
imated by carbon emissions since they constitute the target measure of climate policies and political agreements. Following the recommendation guidelines of the Task Force on Climate-Related Financial Disclosures [38] and thus the industry standard in disclosing carbon information for investors, we use carbon intensity as our measure of interest. Our study is most closely related to Wan et al. [39] and Mukanjari and Sterner [40]. The former compares Chinese fossil fuel and clean energy firms during the COVID-19 period, whereas the latter assesses European stock performance during the crisis period based on carbon intensities. Instead of constraining our study to a certain region, we employ a global stock sample. Moreover, to the best of our knowledge, we are the first to address post-crisis implications, i.e., we investigate how investors incorporate carbon characteristics in their valuations in more stable times following the initial COVID-19 shock period.

A first descriptive analysis demonstrates that high-emitting stocks had significantly lower returns and higher traditional risk measures than low-emitting stocks during the COVID-19 period. In cross-sectional regressions, we find that carbon intensity indeed influenced cumulative returns and abnormal returns negatively during the crisis period. This impact strengthens the higher a stock's carbon intensity level. To infer whether the effect is unique to the crisis period and not common to the previous, rather calm economic time, we conduct difference-in-differences regressions on daily return measures. We confirm that high emitters experienced a significantly lower financial performance during the COVID-19 period compared to the pre-crisis period. Hence, investors rather shunned these stocks in times of high economic uncertainty and drove returns of carbon-intensive stocks down. In the post-COVID-19 period, however, high emitters achieved a significantly higher performance than in the pre-crisis period, thus allowing them to make up for some of their additional losses incurred during the crisis period compared to low emitters.

Cross-sectional regressions with volatility and idiosyncratic volatility as dependent variables show that carbon intensity had no significant impact on risk during the crisis period. The major drivers of risk in this period were other firm characteristics such as debt, profitability, and historical volatility. However, high emitters turned out to be significantly riskier relative to low emitters. Eventually, for the post-COVID-19 period, the effect of carbon intensity on volatility turned significantly positive. Increasing risk for carbonintensive stocks is in line with their higher risk exposure towards stranded assets and climate policy regulation targeted at reducing carbon emissions. Moreover, discussions on combining monetary economic stimulus packages with climate change targets might have magnified risk exposures for carbon-based assets. Apart from that, our results in the post-crisis period, i.e., higher risk exposure and higher returns for carbon-intensive stocks, are in line with discussions about the existence of a carbon premium in the financial market [7].

In summary, carbon-intensive stocks had to suffer from lower returns during the unexpected COVID-19 period and displayed higher risk exposures afterwards. Our results emphasize the importance of fully incorporating climate risks in stock valuation practices as an essential driver of unexpectedly changing future cash flows and discount rates. Climate risks constitute an unavoidable risk source and thus have to be part of sound risk management strategies. Our analyses point to the fact that market participants have already shunned carbon-intensive stocks during the COVID-19 shock period driving their returns downward. In addition, increased societal and political interest in a green economic development-exemplified by green recovery packages_impose an ever higher risk burden on carbon-based stocks. Overall, this study supports financial market participants in deriving more profound forecasts and stock recommendations, constructing more resilient portfolios, and eventually avoiding excessive risk-taking due to an unidentified risk source.

\section{Data Description}

For our empirical analyses, we use a global stock sample based on stocks of the MSCI All Countries World Investable Market Index (ACWI IMI). We obtain scope 1 and scope 2 carbon emissions data from three sources: CDP, Refinitiv, and Sustainalytics. Since 
reporting of carbon emission levels is not mandatory yet, we have to face limited data availability. To overcome this shortcoming, we enlarge our data sample by combining the aforementioned databases. If no CDP emissions are available for a stock, the data point is filled by Refinitiv and eventually Sustainalytics. In our analyses, we use carbon intensity defined as the sum of scope 1 and 2 emissions divided by a firm's net sales. This is a standard approach for measuring carbon intensity in research [7] and finance practice [38]. Emissions data refer to 2019 yearly values. Thus, we use the information on carbon intensity that was available in the markets for investors before the exogenous shock hit. Usually, data on emissions are reported on an annual basis. Thus, 2019 carbon intensity levels were the most recent information available to investors during and beyond the COVID-19 crisis period. In this way, we can analyze investor preferences over time without the impact of changing carbon intensity levels of firms. To distinguish between high and low carbon-intensive stocks more rigidly, we label all stocks with a carbon intensity higher than the 75th percentile as "high emitters" and the remaining stocks as "low emitters".

We obtain daily return data from Refinitiv Datastream for the years 2019 and 2020. Furthermore, we extract December 2019 accounting data known to influence returns, i.e., size measured by the logarithm of market capitalization, total debt over total assets, cash holdings over total assets, the leverage ratio, return on equity as profitability measure, expenses for selling, general and administrative functions (SGAE), the dividends ratio, and the book value of equity for calculating the book-to-market ratio. We additionally define historical volatility as a stock's daily return volatility during the year 2019. Our key variables are defined as follows. Apart from daily raw excess returns, we calculate abnormal daily returns as the difference between raw excess returns and CAPM-adjusted excess returns. Both for the COVID-19 and post-COVID-19 periods, we compute cumulative returns and cumulative abnormal returns. In addition, return volatility and idiosyncratic volatility (defined as abnormal return volatility) during each period serve as risk measures. Overall, with these definitions, we follow prior studies such as Ramelli and Wagner [24], Albuquerque et al. [28], and Lins et al. [26].

Descriptive statistics of all variables used in this article are summarized in Table 1. In total, we obtain carbon intensity data for 3247 stocks. At the intersection of all relevant data points for our baseline analyses, we are left with 2589 global stocks.

In order to obtain clear-cut results for the impact of the COVID-19 pandemic, we define a more intensive crisis period for COVID-19 from 24 February until 31 March 2020 in line with previous papers (the start of the "fever period" in Ramelli and Wagner [24] and the "COVID-19 event date" in Albuquerque et al. [28]). The subsequent period from 1 April 2020 until the end of the year is defined as the post-COVID-19 or post-crisis period. Even though the COVID-19 pandemic still defines our daily lives one year after the global outbreak, stock markets recovered fairly well from April 2020 on. We explain this circumstance by the fact that the first outbreak and the following lockdowns in February 2020 have been surprising and until then unique in nature. Hence, they constituted an unforeseen shock event. After that, further waves and consequential lockdowns have been expected and propagated by health experts and economists. Stock analysts thus had the possibility to take potential impacts on financial assets into account in their valuation processes. In fact, we did not observe another severe market downturn following March 2020.

As a first motivation for our study, we have a look at the stock market performance and the performance of the high-emitter (brown) and low-emitter (green) portfolio during 2020 in Figure 1. For the stock market, we take the MSCI ACWI IMI as a basis and report both equal- and value-weighted brown and green portfolios. 
Table 1. Descriptive statistics.

\begin{tabular}{ccccccc}
\hline Variable & N & Mean & SD & P25 & Median & P75 \\
\hline Carbon Intensity & 3247 & 0.3374 & 1.3581 & 0.0088 & 0.0371 & 0.2025 \\
Cum. Ret. COVID-19 & 3234 & -0.2789 & 0.1536 & -0.3830 & -0.2697 & -0.1678 \\
Cum. Ret. post-COVID-19 & 3230 & 0.6401 & 0.5086 & 0.2554 & 0.5291 & 0.8811 \\
Cum. AR COVID-19 & 3245 & -0.1127 & 0.1859 & -0.2393 & -0.1114 & 0.0207 \\
Cum. AR post-COVID-19 & 3230 & 0.1626 & 0.4123 & -0.1292 & 0.0653 & 0.3615 \\
Volatility COVID-19 & 3245 & 0.0584 & 0.0208 & 0.0424 & 0.0549 & 0.0703 \\
Volatility post-COVID-19 & 3245 & 0.0493 & 0.0178 & 0.0361 & 0.0453 & 0.0587 \\
Idio. Volatility COVID-19 & 3230 & 0.0276 & 0.0093 & 0.0206 & 0.0258 & 0.0326 \\
Idio. Volatility post-COVID-19 & 3230 & 0.0255 & 0.0089 & 0.0188 & 0.0238 & 0.0300 \\
Size & 2977 & 15.5062 & 1.3882 & 14.4591 & 15.4784 & 16.5134 \\
Debt & 2916 & 0.2837 & 0.1656 & 0.1506 & 0.2783 & 0.4046 \\
Profitability & 2862 & 0.1093 & 0.1105 & 0.0473 & 0.1005 & 0.1625 \\
Cash Intensity & 2724 & 0.0860 & 0.0729 & 0.0283 & 0.0653 & 0.1238 \\
SGAE Intensity & 3247 & 0.0921 & 0.1077 & 0.0000 & 0.0487 & 0.1492 \\
Historical Volatility & 3247 & 0.0184 & 0.0059 & 0.0137 & 0.0175 & 0.0222 \\
Dividends & 3247 & 0.7989 & 1.3879 & 0.0193 & 0.0653 & 0.8850 \\
BTM & 3180 & 0.6905 & 0.4949 & 0.3003 & 0.5780 & 0.9524 \\
Daily Return & 826,568 & 0.0538 & 3.2432 & -1.3899 & 0.0118 & 1.4601 \\
Daily Abnormal Return & 826,568 & -0.0030 & 2.8618 & -1.3690 & -0.0678 & 1.2658 \\
\hline
\end{tabular}

This table provides descriptive statistics of all variables used in this study. The (abnormal) cumulative return and (idiosyncratic) volatility are given for each respective period. Carbon intensity is defined as the sum of scope 1 and 2 emissions over net sales. Control variables are defined as follows: size is measured as the natural logarithm of the market capitalization. Debt represents total debt over total assets. Profitability is measured by the return on equity calculated as net income less preferred dividend requirements over the average of last year's and current year's common equity. Cash intensity represents cash holdings over total assets. SGAE intensity represents the expenses for selling, general, and administrative functions over total assets. The historical volatility is the daily return volatility of a firm during 2019 . Dividends are measured as a ratio to the stock price. The book-to-market ratio (BTM) is calculated as a firm's book value over its market value. Daily (abnormal) return is given in percent.

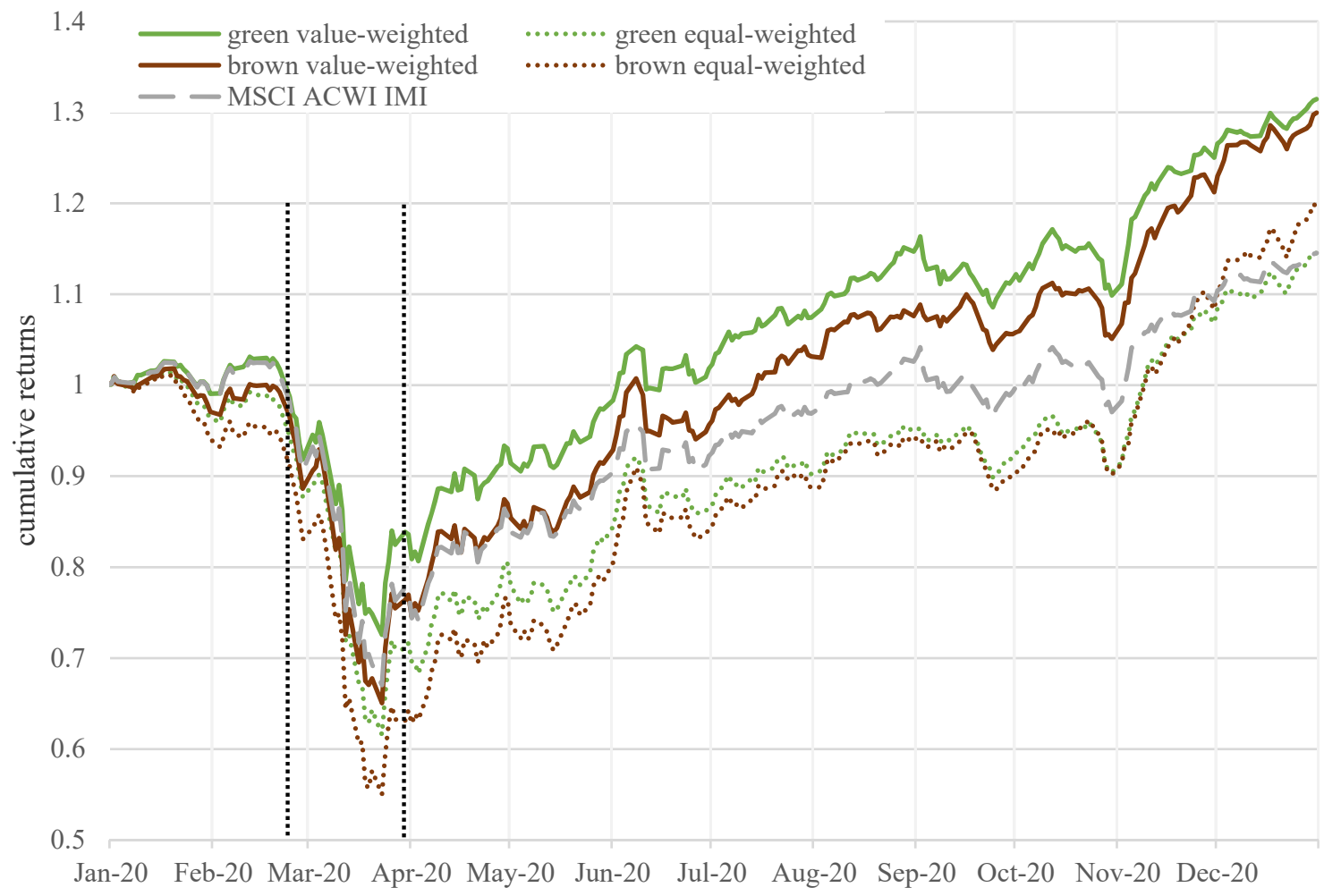

Figure 1. Stock performance during the year 2020. This figure plots the development of the MSCI ACWI IMI and four stock portfolios from 1 January 2020 to 31 December 2020. The brown and green colors indicate portfolios consisting of the highand low-emitting firms, respectively. The vertical lines enclose the COVID-19 period as defined in the text. 
In line with the overall market, the decline in the portfolio performance was limited to the COVID-19 period from 24 February to 31 March. After that, both portfolios recovered from this shock. Moreover, the high emitters (brown portfolio) declined more in the crisis period, but were able to recover their additionally incurred loss in the course of the year compared to the green portfolio. The aim of this study is to elaborate on this observation and find proof that market participants incorporate carbon intensity in their valuation processes of assets.

\section{Methodological Framework}

In a first step, we determine the influence of carbon intensity on daily stock returns during the COVID-19 and post-COVID-19 period. For this purpose, we use cross-sectional regressions following Equation (1).

$$
\begin{gathered}
r_{i}=\beta_{0}+\beta_{1} \text { carbon_int }_{i}+\beta_{k} \text { controls }_{i}+ \\
\delta \text { ind_fixed_effects }{ }_{i}+\gamma \text { country_fixed_effects }{ }_{i}+\varepsilon_{i}
\end{gathered}
$$

where $r_{i}$ is the performance measure of stock $i$ in the respective period, carbon_int ${ }_{i}$ its carbon intensity, and controls $s_{i}$ a vector of firm characteristics at their 2019 values including size, debt, profitability, cash intensity, SGAE intensity, historical volatility, dividends, and the book-to-market ratio. Previous studies demonstrate that these stock characteristics influence firm performance. Daniel and Titman [41] find that size and the book-to-market ratio explain variation in stock returns. The level of debt, profitability, and cash intensity determine a firm's financial health especially during crisis times (see, e.g., [23,24,26]). In addition, we include SGAE intensity, historical volatility, and dividends to account for further important firm characteristics (following [28]). By including these firm-specific characteristics, we ensure that the return-influencing effect we attribute to carbon intensity is not driven by other factors correlated with carbon intensity, i.e., we minimize the impact of omitted variable bias in our study.

As performance measures, we use both the cumulative daily excess return and the cumulative abnormal return over the respective period. We also include industry and country fixed effects. In this way, we take into account that industries and countries were impacted differently by the COVID-19 shock [14,42]. In addition, climate policies targeted at the reduction of carbon emissions vary greatly among countries and have different impacts on industries. For example, while the European Union takes over a leadership role in the area of climate action, the USA relaxed environmental regulations under the Trump administration rendering their climate action critically insufficient. (Climate Action Tracker provides a comprehensive overview and analysis of climate action by country and sector: https: / / climateactiontracker.org/ (accessed on 13 September 2021)). The inclusion of fixed effects thus avoids that the coefficient of carbon intensity, $\beta_{1}$, captures mere industry and country effects.

Equation (1) serves as our baseline model. In subsequent analyses, we divide stocks into carbon intensity quartiles and replace carbon_int $t_{i}$ with dummies for the quartiles two to four. The lowest quartile thus constitutes the reference group. This altered model allows us to dissect the effects of carbon intensity in a more detailed way dependent on the level of carbon intensity.

In a second step, we estimate the effect of carbon intensity on both the total and idiosyncratic volatility of stocks in the crisis and post-crisis period. For this purpose, we use a stock's excess return volatility and its abnormal return volatility (as idiosyncratic volatility) in the respective time period as dependent variables in Equation (1).

For the validity of our study, it is important that the influence of carbon intensity significantly changed during the crisis or post-crisis period compared to the pre-crisis period. Under this circumstance, we can conclude that investors incorporate carbon intensity as a fundamental characteristic in their asset re-evaluations during shock periods and beyond and attribute value-influencing traits to carbon emissions. 
To infer whether investors evaluate carbon intensity significantly differently during extreme shock periods and pre- and post-shock times, we make use of a difference-indifferences model following Lins et al. [26], Bouslah et al. [35], and Albuquerque et al. [28]:

$$
\begin{aligned}
& r_{i, t}=\beta_{1} \text { treated }_{i} \times \text { COVID }_{t}+\beta_{2} \text { treated }_{i} \times \text { Post }- \text { COVID }_{t}+ \\
& \beta_{3} \text { treated }_{i}+\beta_{4} \text { COVID }_{t}+\beta_{5} \text { Post }_{-} \text {COVID }_{t}+\beta_{k} \text { controls }_{i}+ \\
& \delta \text { ind_fixed_effects } s_{i}+\gamma \text { country_fixed_effects } s_{i}+\varepsilon_{i}
\end{aligned}
$$

where $r_{i, t}$ is the daily excess return or abnormal return of stock $i$ at time $t$, treated $_{i}$ is a dummy variable equal to one for stocks in the highest quartile measured by carbon intensity, COVID $t$ a dummy variable equal to one for all days between February 24 and March 31, and Post - COVID $t$ a dummy that identifies days between April 2020 and December 2020. The regression is run based on observations from January 2020 to December 2020. Therefore, we also capture a pre-crisis period with this setup. Furthermore, we include the same control variables as in Equation (1) and industry and country fixed effects. Hence, our results are not distorted by firm-specific, industry, or country effects. Standard errors are clustered at the firm level.

Our main measures of interest are the coefficients of the interaction terms. The coefficient $\beta_{1}\left(\beta_{2}\right)$ describes the additional return effect high emitters had to face explicitly during the COVID-19 (post-COVID-19) period. If $\beta_{1}\left(\beta_{2}\right)$ is significantly different from zero, we observe a significant difference between the pre-crisis and the COVID-19 period (postcrisis period) for high emitters. $\beta_{3}$ captures the return effect for high emitters compared to low emitters in the pre-crisis period. $\beta_{4}$ and $\beta_{5}$ mirror performance impacts of the crisis and post-crisis period, respectively. The total return effect for high emitters in the crisis period amounts to $\beta_{1}+\beta_{3}+\beta_{4}$, and for the post-crisis period to $\beta_{2}+\beta_{3}+\beta_{5}$.

\section{Key Characteristics of High Versus Low Emitters}

We start with a simple comparison of key performance and risk indicators during the COVID-19 and post-COVID-19 period for high and low emitters. By construction, average carbon intensity levels are far higher for high emitters than low emitters (see Table 2). During the crisis period, mean and median daily returns were significantly lower for high emitters, whereas all volatility measures point to a higher riskiness of carbon-intensive stocks. For example, the maximum drawdown amounted to $40.68 \%$ for high emitters in contrast to $37.36 \%$ for low emitters. The value at risk (VaR) at a $95 \%$ confidence level was $1.86 \%$ significantly lower (i.e., riskier) for carbon-intensive stocks. With $99 \%$ confidence, investors had to face an additional worst daily loss of $2.85 \%$ for high emitters.

In line with expectations, during the post-COVID-19 period, daily returns turned positive and risk measures were only a fraction of those during the crisis period. For example, the maximum drawdown values reduced to a tenth of those during the COVID19 period. This underlines the severity of the stock market crash during February and March 2020. Levels of daily returns were comparable between the two groups, whereas risk measures were higher for carbon-intensive stocks taking account of their higher climate risk exposure. Solely the maximum drawdown displayed no significant differences.

In summary, we find significant differences in key return and risk indicators of high versus low emitters. In the following, we analyze how far these differences arise due to carbon intensity having entered the valuation process of market participants. 
Table 2. Comparison of key characteristics between high and low carbon emitters during and after the COVID-19 period.

\begin{tabular}{|c|c|c|c|c|}
\hline & \multicolumn{2}{|c|}{ COVID-19 } & \multicolumn{2}{|c|}{ Post-COVID-19 } \\
\hline & (1) & (2) & (3) & (4) \\
\hline & High Emitters & Low Emitters & High Emitters & Low Emitters \\
\hline Carbon Intensity & 0.7306 & $\begin{array}{c}0.0369 \\
\left(0.6937^{* * *}\right)\end{array}$ & 0.7333 & $\begin{array}{c}0.0371 \\
\left(0.6961^{* * *}\right)\end{array}$ \\
\hline Mean Daily Return & -0.0132 & $\begin{array}{c}-0.0107 \\
\left(-0.0025^{* * *}\right)\end{array}$ & 0.0033 & $\begin{array}{c}0.0025 \\
\left(0.0008^{* * *}\right)\end{array}$ \\
\hline Median Daily Return & -0.0146 & $\begin{array}{c}-0.0128 \\
\left(-0.0018^{* * *}\right)\end{array}$ & 0.0013 & $\begin{array}{c}0.0012 \\
(0.0001)\end{array}$ \\
\hline Volatility & 0.0684 & $\begin{array}{c}0.0571 \\
\left(0.0113^{* * *}\right)\end{array}$ & 0.0321 & $\begin{array}{c}0.027 \\
\left(0.0051^{* * *}\right)\end{array}$ \\
\hline VaR 25\% & -0.0509 & $\begin{array}{c}-0.0426 \\
\left(-0.0082^{* * *}\right)\end{array}$ & -0.0147 & $\begin{array}{c}-0.0128 \\
\left(-0.0020^{* * *}\right)\end{array}$ \\
\hline VaR $10 \%$ & -0.0968 & $\begin{array}{c}-0.0818 \\
\left(-0.0150^{* * *}\right)\end{array}$ & -0.0311 & $\begin{array}{c}-0.0271 \\
\left(-0.0039^{* * *}\right)\end{array}$ \\
\hline VaR 5\% & -0.1188 & $\begin{array}{c}-0.1001 \\
\left(-0.0186^{* * *}\right)\end{array}$ & -0.043 & $\begin{array}{c}-0.0376^{*} \\
\left(-0.0054^{* * *}\right)\end{array}$ \\
\hline VaR $1 \%$ & -0.1619 & $\begin{array}{c}-0.1334 \\
\left(-0.0285^{* * *}\right)\end{array}$ & -0.0769 & $\begin{array}{c}-0.0662 \\
\left(-0.0106^{* * *}\right)\end{array}$ \\
\hline Maximum Drawdown & 0.4068 & $\begin{array}{c}0.3736 \\
\left(0.0332^{* * *}\right)\end{array}$ & 0.0428 & $\begin{array}{c}0.0441 \\
(-0.0014)\end{array}$ \\
\hline Observations & 811 & 2433 & 807 & 2423 \\
\hline
\end{tabular}

This table provides a comparison of different key characteristics for high and low carbon emitters in the COVID-19 period and the post-COVID-19 period return, volatility, VaR, and maximum drawdown measures are given in absolute values. Differences (high emitters-low emitters) and their significance levels are displayed in parentheses. ${ }^{* * *},{ }^{* *}$, and ${ }^{*}$ indicate significance at the $1 \%, 5 \%$, and $10 \%$ level, respectively.

\section{The Interconnection between Carbon Intensity and Performance}

Table 3 summarizes the results of our baseline model. During the COVID-19 period, carbon intensity had a significant negative effect on both raw and abnormal cumulative returns. To be more specific, an increase of one standard deviation in carbon intensity (1.3581) decreased cumulative daily (abnormal) returns by $0.3667 \%(1.3581 \times 0.0027)$ and $0.4482 \%$, respectively. Hence, carbon intensity had a higher impact on stock-specific abnormal returns compared to cumulative returns. Even though the return impacts appear small in nature, we have to bear in mind that this effect relates only to 27 trading days (the COVID-19 period). The annual return loss would amount to around $3.40 \%$ and $4.15 \%$ for a one-standard-deviation increase in carbon intensity, which emphasizes its economic significance. For this approximation, we break down the effect during the COVID-19 period on one day and subsequently scale it to 250 trading days.

Besides that, we can confirm results of previous studies that lower debt and higher cash had a significant positive influence on returns during the pandemic period [24,28]. In addition, larger and more profitable firms achieved significantly higher performance during COVID-19 (in line with [24,28]). High historical volatility impacted cumulative returns negatively, but had a reverse effect on abnormal returns. This shows a stock's high dependence on systematic risk exposures.

After the exogenous shock, the significant impact of carbon intensity vanishes (columns (3) and (4)). Our results point to the fact that investors facing a period of high uncertainty are more aware of long-term risks and increase their stakes in potential safe-haven stocks. The COVID-19 pandemic has proven that a highly improbable risk can suddenly materialize. Climate risks, in contrast, are far from being improbable to occur-they will materialize either in form of physical impacts or policy regulations. Thus, investors might have drawn the conclusion to withdraw their funds from riskier and potential stranded assets driving the performance of such assets downwards. In the recovery period, however, there was no reversal or multiplier effect of carbon intensity on returns because investors had already revised their stock valuations during the crisis period. 
Table 3. Influence of carbon intensity on financial performance during and after the COVID-19 period.

\begin{tabular}{|c|c|c|c|c|}
\hline & \multicolumn{2}{|c|}{ COVID-19 } & \multicolumn{2}{|c|}{ Post-COVID-19 } \\
\hline & (1) & (2) & (3) & (4) \\
\hline & Return & Abnormal Return & Return & Abnormal Return \\
\hline Carbon Intensity & $\begin{array}{c}-0.0027^{* * *} \\
(-2.85)\end{array}$ & $\begin{array}{c}-0.0033 \text { ** } \\
(-2.51)\end{array}$ & $\begin{array}{l}-0.0039 \\
(-0.81)\end{array}$ & $\begin{array}{l}-0.0032 \\
(-0.67)\end{array}$ \\
\hline Size & $\begin{array}{c}0.0074^{* * *} \\
(3.57)\end{array}$ & $\begin{array}{c}0.030 * * * \\
(10.57)\end{array}$ & $\begin{array}{l}0.012 \\
(1.53)\end{array}$ & $\begin{array}{c}-0.043^{* * *} \\
(-6.30)\end{array}$ \\
\hline Debt & $\begin{array}{c}-0.068^{* * *} \\
(-4.76)\end{array}$ & $\begin{array}{c}-0.063^{* * * *} \\
(-3.09)\end{array}$ & $\begin{array}{l}0.071 \\
(1.21)\end{array}$ & $\begin{array}{l}0.063 \\
(1.26)\end{array}$ \\
\hline Profitability & $\begin{array}{c}0.15^{* * *} \\
(5.99)\end{array}$ & $\begin{array}{c}0.19 * * * \\
(5.29)\end{array}$ & $\begin{array}{l}-0.17 \\
(-1.64)\end{array}$ & $\begin{array}{l}-0.40^{* * *} \\
(-4.72)\end{array}$ \\
\hline Cash Intensity & $\begin{array}{c}0.15^{* * *} \\
(4.53)\end{array}$ & $\begin{array}{c}0.29^{* * * *} \\
(6.08)\end{array}$ & $\begin{array}{l}0.057 \\
(0.41)\end{array}$ & $\begin{array}{l}-0.088 \\
(-0.74)\end{array}$ \\
\hline SGAE Intensity & $\begin{array}{l}-0.0031 \\
(-0.12)\end{array}$ & $\begin{array}{l}0.062 \\
(1.64)\end{array}$ & $\begin{array}{c}0.11 \\
(1.00)\end{array}$ & $\begin{array}{l}0.15^{*} \\
(1.73)\end{array}$ \\
\hline Historical Volatility & $\begin{array}{l}-5.80 * * * \\
(-10.83)\end{array}$ & $\begin{array}{l}1.52^{* *} \\
(2.01)\end{array}$ & $\begin{array}{l}34.6^{* * *} \\
(15.57)\end{array}$ & $\begin{array}{c}7.57^{* * *} \\
(4.07)\end{array}$ \\
\hline Dividends & $\begin{array}{c}-0.0054^{*} \\
(-1.76)\end{array}$ & $\begin{array}{l}-0.0020 \\
(-0.48)\end{array}$ & $\begin{array}{l}-0.015 \\
(-1.33)\end{array}$ & $\begin{array}{l}-0.0083 \\
(-0.83)\end{array}$ \\
\hline BTM & $\begin{array}{l}-0.0090 \\
(-1.46)\end{array}$ & $\begin{array}{c}0.049 * * * \\
(5.52)\end{array}$ & $\begin{array}{l}-0.0055 \\
(-0.20)\end{array}$ & $\begin{array}{c}0.070 * * * \\
(2.95)\end{array}$ \\
\hline Industry fixed effects & Yes & Yes & Yes & Yes \\
\hline Country fixed effects & Yes & Yes & Yes & Yes \\
\hline Observations & 2589 & 2589 & 2587 & 2587 \\
\hline Adjusted $R^{2}$ & 0.4937 & 0.3329 & 0.3544 & 0.2689 \\
\hline
\end{tabular}

This table provides the results of cross-sectional regressions for the COVID-19 period and the post-COVID-19 period. The dependent variable is defined as the (abnormal) cumulative return during the respective period. All variables are as defined in Table 1. Industry and country fixed effects are included in all specifications and heteroscedasticity-robust standard errors are estimated. T-statistics are provided in parentheses. ${ }^{* * *},{ }^{* *}$, and ${ }^{*}$ indicate significance at the $1 \%, 5 \%$, and $10 \%$ level, respectively.

In our second analysis of the relationship between carbon intensity and financial performance, we dissect this effect further. We re-run our baseline model and replace the carbon intensity measure with dummy variables indicating the quartile group of stocks based on their carbon intensity. We exclude the dummy variable for quartile one, so that all effects are estimated relative to our lowest-emitting group.

High emitters achieved a 2.8\% lower cumulative return in the COVID-19 period compared to low emitters (Table 4, column (1)). The return difference to low emitters decreases the more similar stocks become with regard to their carbon intensity measure. Medium emitters have a $1.9 \%$ lower return than low emitters, whereas there are no significant differences between the two lowest emitting quartiles. We find an even more pronounced pattern for abnormal cumulative returns (column (2)). High emitters lost a significant 3.6\% in abnormal returns compared to low-emitting stocks. This return difference diminishes to $1.9 \%$ for lower emitting stocks.

In the post-COVID-19 period, the effect reverses but is not statistically significant anymore. Hence, during the calmer post-COVID-19 period, there was no significant difference between the carbon groups. In other words, during the recovery phase, the level of carbon intensity did not drive return patterns. This result reinforces our conclusions drawn from Table 3. Overall, this analysis emphasizes that the higher the carbon intensity of stocks, the higher their performance loss during the shock period.

Following Lins et al. [26] and Albuquerque et al. [28], we conduct a difference-indifferences regression to investigate whether our return effect is uniquely found for the COVID-19 period or common to most periods. Table 5 contains the results both for daily excess and abnormal returns. The treated variable equals 1 for high emitters, i.e., stocks with a carbon intensity in the highest quartile. 
Table 4. Influence of carbon intensity quartiles on financial performance during and after the COVID-19 period.

\begin{tabular}{|c|c|c|c|c|}
\hline & \multicolumn{2}{|c|}{ COVID-19 } & \multicolumn{2}{|c|}{ Post-COVID-19 } \\
\hline & (1) & (2) & (3) & (4) \\
\hline & Return & Abnormal Return & Return & Abnormal Return \\
\hline High Emitter & $\begin{array}{c}-0.028^{* * *} \\
(-3.18)\end{array}$ & $\begin{array}{c}-0.036 \text { *** } \\
(-2.84)\end{array}$ & $\begin{array}{l}0.045 \\
(1.27)\end{array}$ & $\begin{array}{l}0.045 \\
(1.48)\end{array}$ \\
\hline Medium Emitter & $\begin{array}{c}-0.019 * * * \\
(-2.68)\end{array}$ & $\begin{array}{c}-0.022 * * \\
(-2.24)\end{array}$ & $\begin{array}{l}0.011 \\
(0.40)\end{array}$ & $\begin{array}{l}0.013 \\
(0.54)\end{array}$ \\
\hline Lower Emitter & $\begin{array}{l}-0.0090 \\
(-1.29)\end{array}$ & $\begin{array}{c}-0.019 * * \\
(-2.01)\end{array}$ & $\begin{array}{l}-0.0055 \\
(-0.21)\end{array}$ & $\begin{array}{l}0.015 \\
(0.67)\end{array}$ \\
\hline Size & $\begin{array}{c}0.0080 * * * \\
(3.87)\end{array}$ & $\begin{array}{c}0.031^{* * *} \\
(10.89)\end{array}$ & $\begin{array}{l}0.011 \\
(1.46)\end{array}$ & $\begin{array}{c}-0.044^{* * *} \\
(-6.39)\end{array}$ \\
\hline Debt & $\begin{array}{c}-0.063^{* * *} \\
(-4.37)\end{array}$ & $\begin{array}{c}-0.056 \text { *** } \\
(-2.77)\end{array}$ & $\begin{array}{l}0.065 \\
(1.12)\end{array}$ & $\begin{array}{l}0.058 \\
(1.16)\end{array}$ \\
\hline Profitability & $\begin{array}{c}0.15^{* * *} \\
(5.91)\end{array}$ & $\begin{array}{c}0.18^{* * *} \\
(5.26)\end{array}$ & $\begin{array}{c}-0.16 \\
(-1.57)\end{array}$ & $\begin{array}{c}-0.39^{* * *} \\
(-4.68)\end{array}$ \\
\hline Cash Intensity & $\begin{array}{c}0.14^{* * *} \\
(4.21)\end{array}$ & $\begin{array}{c}0.27 * * * \\
(5.86)\end{array}$ & $\begin{array}{l}0.074 \\
(0.53)\end{array}$ & $\begin{array}{l}-0.073 \\
(-0.61)\end{array}$ \\
\hline SGAE Intensity & $\begin{array}{l}-0.013 \\
(-0.50)\end{array}$ & $\begin{array}{l}0.052 \\
(1.34)\end{array}$ & $\begin{array}{c}0.12 \\
(1.17)\end{array}$ & $\begin{array}{l}0.17 * \\
(1.86)\end{array}$ \\
\hline Historical Volatility & $\begin{array}{l}-5.75^{* * *} \\
(-10.77)\end{array}$ & $\begin{array}{l}1.59 \text { ** } \\
(2.12)\end{array}$ & $\begin{array}{l}34.6^{* * *} \\
(15.56)\end{array}$ & $\begin{array}{c}7.54^{* * *} \\
(4.05)\end{array}$ \\
\hline Dividends & $\begin{array}{c}-0.0052 * \\
(-1.70)\end{array}$ & $\begin{array}{l}-0.0017 \\
(-0.40)\end{array}$ & $\begin{array}{l}-0.015 \\
(-1.35)\end{array}$ & $\begin{array}{l}-0.0089 \\
(-0.89)\end{array}$ \\
\hline BTM & $\begin{array}{l}-0.0068 \\
(-1.10)\end{array}$ & $\begin{array}{c}0.052 * * * \\
(5.79)\end{array}$ & $\begin{array}{l}-0.0097 \\
(-0.35)\end{array}$ & $\begin{array}{c}0.066^{* * *} \\
(2.79)\end{array}$ \\
\hline Industry fixed effects & Yes & Yes & Yes & Yes \\
\hline Country fixed effects & Yes & Yes & Yes & Yes \\
\hline Observations & 2589 & 2589 & 2587 & 2587 \\
\hline Adjusted $R^{2}$ & 0.4951 & 0.3342 & 0.3546 & 0.2690 \\
\hline
\end{tabular}

This table provides the results of cross-sectional regressions for the COVID-19 period and the post-COVID-19 period. The dependent variable is defined as the (abnormal) cumulative return during the respective period. We use dummy variables for carbon intensity quartiles. Control variables are as defined in Table 1 . Industry and country fixed effects are included in all specifications and heteroscedasticityrobust standard errors are estimated. T-statistics are provided in parentheses. ${ }^{* * *},{ }^{* *}$, and ${ }^{*}$ indicate significance at the $1 \%, 5 \%$, and $10 \%$ level, respectively.

Compared to the pre-COVID-19 period, stocks lost $0.96 \%$ in performance during COVID-19. In contrast, returns in the post-COVID-19 period were higher by $0.31 \%$. This mirrors the fast recovery of the overall stock market during the course of the year 2020. High emitters lost an additional $0.099 \%$ in return compared to low emitters in the pre-crisis period. More importantly, high emitters had to forgo an additional $0.17 \%$ in performance compared to low emitters in the COVID-19 period. This effect is statistically significant, so that we conclude that high emitters had to suffer significantly more during the shock period compared to the more stable pre-crisis period. In the post-COVID-19 period, in contrast, high emitters gained an additional significant $0.15 \%$ compared to the pre-crisis period. Hence, even the post-crisis period differed significantly from the pre-crisis period in that carbon-intensive stocks recovered faster. In summary, the total return effect for high emitters in the COVID-19 (post COVID-19) period amounted to $-1.229 \%(0.361 \%)$, which is significantly different to the pre-crisis period.

This reinforces our previous results that investors modified their valuations of carbonintensive stocks and valued them lower in times of high uncertainty. In the post-COVID-19 time, however, carbon-intensive stocks could recover more than low emitters. Higher returns also speak for the fact that investors might demand a premium for holding carbonrisky stocks as suggested by Bolton and Kacperczyk [7], for example.

In order to assess how far the relevance of carbon intensity for returns changed over time, we plot the evolution of the coefficient of carbon intensity obtained in a recursive window regression with daily excess returns as dependent variable and the control variables of Equation (1) as further independent variables (similar to Ramelli and Wagner [24]). For the first estimation at the beginning of the year 2020, we use data for all trading days during 2019, and, for each further day, we add the additional day to our estimation window. 
Table 5. Difference-in-differences model results.

\begin{tabular}{ccc}
\hline & $\mathbf{( 1 )}$ & $\mathbf{( 2 )}$ \\
\cline { 2 - 3 } & Return & Abnormal Return \\
\cline { 2 - 3 } High Emitter $\times$ COVID & $-0.0017^{* * *}$ & $-0.0013^{* * *}$ \\
High Emitter $\times$ Post-COVID & $(-4.46)$ & $(-3.03)$ \\
& $0.0015^{* * *}$ & $0.0015^{* * *}$ \\
High Emitter & $(8.30)$ & $(8.50)$ \\
& $-0.00099^{* * *}$ & $-0.00098^{* * *}$ \\
COVID-19 & $(-6.27)$ & $(-5.88)$ \\
& $-0.0096^{* * *}$ & $-0.0023^{* * *}$ \\
Post-COVID-19 & $(-51.19)$ & $(-12.39)$ \\
& $0.0031^{* * *}$ & $0.0015^{* * *}$ \\
Controls & $(40.46)$ & $(19.72)$ \\
Industry fixed effects & Yes & Yes \\
Country fixed effects & Yes & Yes \\
Observations & Yes & Yes \\
Adjusted $R^{2}$ & 644,255 & 644,255 \\
& 0.01789 & 0.003481
\end{tabular}

This table presents results of difference-in-differences regressions for daily excess and abnormal returns. High emitter equals one for high carbon intensity firms in the last carbon intensity quartile and zero otherwise. COVID-19 equals one from 24 February 2020 to 31 March 2020, and Post-COVID-19 equals one from 1 April 2020 to 31 December 2020. Control variables, industry, and country fixed effects are included in all specifications. Standard errors are clustered at the firm level. T-statistics are provided in parentheses. ${ }^{* * *}$ indicates significance at the $1 \%$ level.

We note that the coefficient remains negative throughout the year (see Figure 2). However, sensitivities towards carbon intensity are especially pronounced in the COVID19 period. The relevance of carbon intensity thus intensified during the uncertain crisis period confirming our previous results. In the post-COVID-19 period, the coefficient is absolutely lower and less volatile but keeps its negative influence on returns.

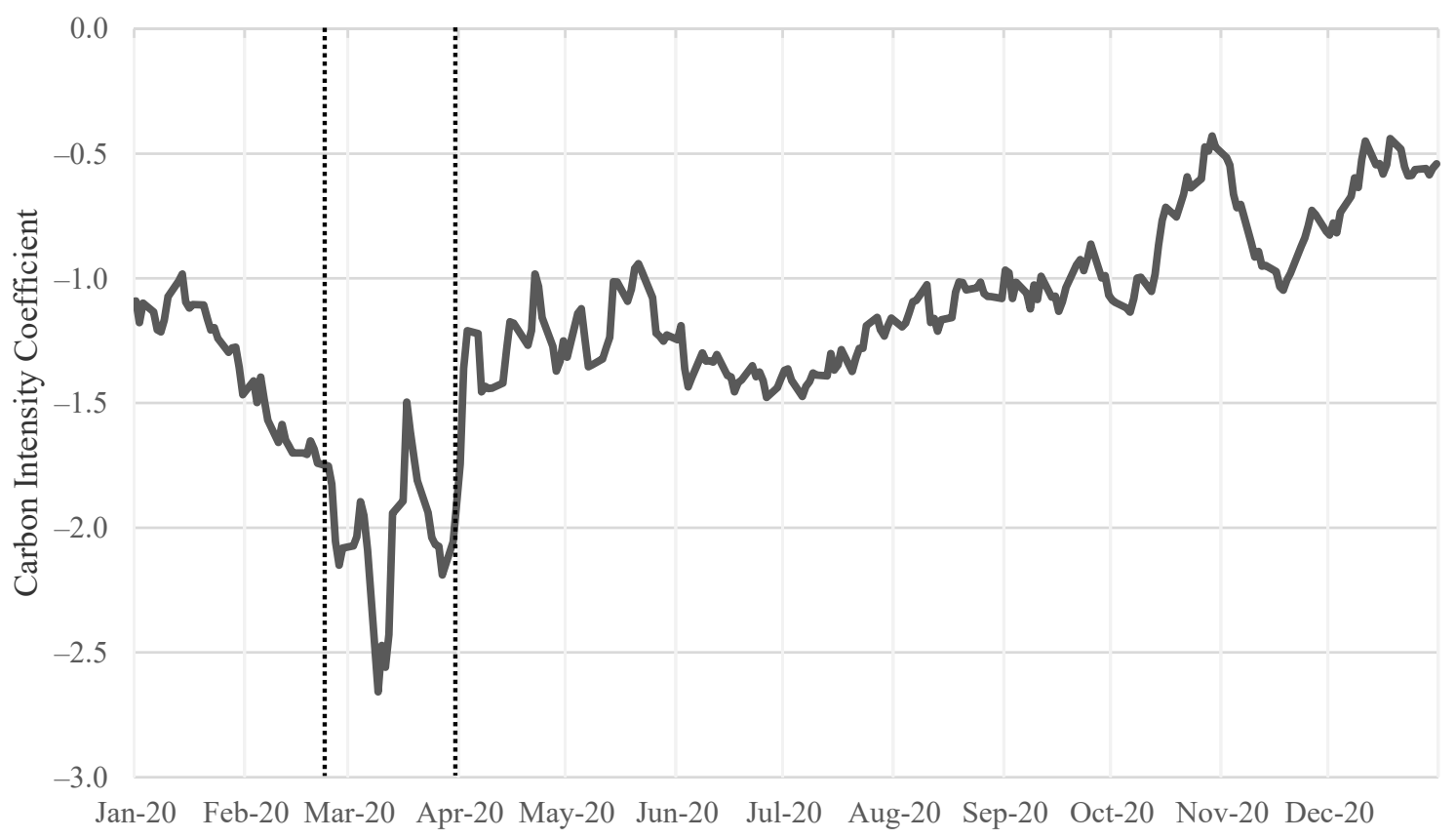

Figure 2. Evolution of the carbon intensity coefficient in the year 2020. This figure plots the daily carbon intensity coefficients (in percent) from panel regressions from 1 January 2020 to 31 December 2020. The panel regressions include all control variables from Table 3 and are estimated in a recursive window starting with all trading days of 2019 for the first estimation. The vertical lines enclose the COVID-19 period. 


\section{The Impact of Carbon Intensity on Risk}

In the previous section, we found that investors re-evaluated especially carbonintensive stocks during the market downturn. Now, we focus on their risk profile during and after the pandemic period. Table 6 repeats the cross-sectional regressions of Table 3 with volatility and idiosyncratic volatility as dependent variables. In columns (1) and (2), we find that carbon intensity had no significant impact on stock risk during the crisis period. Risk was rather driven by other fundamentals such as debt, profitability, SGAE intensity, historical volatility, and dividends. The pattern changes in the post-COVID-19 period (columns (3) and (4)). Carbon intensity influenced stock volatility and idiosyncratic volatility significantly positive. In more stable times, carbon intensity drives stock risk. This is in line with the argumentation that carbon-intensive stocks face higher long-term risks. Furthermore, in the aftermath of the first lockdown, discussions heightened on whether to use economic stimulus packages to drive the long-term transition towards a low-carbon economy [40,43]. Shan et al. [44] state that fiscal stimulus plans can either be a threat to global climate change mitigation or a jumpstart to achieve emission targets. For example, as of March 2021, the Energy Policy Tracker estimates that around 36\% of monetary commitments for the energy sector in G20 countries are targeted towards the production and consumption of fossil fuels [45]. Investing in carbon-intensive assets increases the risk of incurring more stranded assets in the future [43]. In either case-support for carbon-intensive assets or green stimulus packages—carbon-intensive stocks have to face higher climate risk exposures.

Table 6. Influence of carbon intensity on risk during and after the COVID-19 period.

\begin{tabular}{|c|c|c|c|c|}
\hline & \multicolumn{2}{|c|}{ COVID-19 } & \multicolumn{2}{|c|}{ Post-COVID-19 } \\
\hline & (1) & (2) & (3) & (4) \\
\hline & Volatility & Idio. Volatility & Volatility & Idio. Volatility \\
\hline Carbon Intensity & $\begin{array}{c}0.000089 \\
(0.70)\end{array}$ & $\begin{array}{c}0.000062 \\
(0.48)\end{array}$ & $\begin{array}{c}0.00018^{* * * *} \\
(2.74)\end{array}$ & $\begin{array}{c}0.00013^{* *} \\
(2.03)\end{array}$ \\
\hline Size & $\begin{array}{c}0.00014 \\
(0.56)\end{array}$ & $\begin{array}{c}-0.00076^{* * *} \\
(-3.11)\end{array}$ & $\begin{array}{c}-0.00068^{* * *} \\
(-5.90)\end{array}$ & $\begin{array}{c}-0.00092^{* * *} \\
(-8.36)\end{array}$ \\
\hline Debt & $\begin{array}{c}0.0077^{* * * *} \\
(4.41)\end{array}$ & $\begin{array}{c}0.0089 * * * \\
(5.24)\end{array}$ & $\begin{array}{c}0.0032 * * * * \\
(4.03)\end{array}$ & $\begin{array}{c}0.0033^{* * * *} \\
(4.16)\end{array}$ \\
\hline Profitability & $\begin{array}{c}-0.013^{* * *} \\
(-4.31)\end{array}$ & $\begin{array}{c}-0.011^{* * *} \\
(-3.72)\end{array}$ & $\begin{array}{c}-0.011^{* * *} \\
(-7.64)\end{array}$ & $\begin{array}{c}-0.0094^{* * *} \\
(-7.10)\end{array}$ \\
\hline Cash Intensity & $\begin{array}{c}-0.0081^{* *} \\
(-2.06)\end{array}$ & $\begin{array}{l}-0.0055 \\
(-1.45)\end{array}$ & $\begin{array}{l}-0.0020 \\
(-1.07)\end{array}$ & $\begin{array}{l}-0.0014 \\
(-0.75)\end{array}$ \\
\hline SGAE Intensity & $\begin{array}{c}-0.0077 * * \\
(-2.35)\end{array}$ & $\begin{array}{c}-0.0076^{* *} \\
(-2.40)\end{array}$ & $\begin{array}{l}0.0013 \\
(0.86)\end{array}$ & $\begin{array}{c}0.00090 \\
(0.62)\end{array}$ \\
\hline Historical Volatility & $\begin{array}{l}1.07^{* * *} \\
(17.72)\end{array}$ & $\begin{array}{l}1.25^{* * *} \\
(19.51)\end{array}$ & $\begin{array}{l}0.77^{* * *} \\
(25.81)\end{array}$ & $\begin{array}{l}0.77^{* * *} \\
(26.78)\end{array}$ \\
\hline Dividends & $\begin{array}{c}-0.00079 * * \\
(-2.26)\end{array}$ & $\begin{array}{c}-0.00058^{*} \\
(-1.68)\end{array}$ & $\begin{array}{c}0.000070 \\
(0.45)\end{array}$ & $\begin{array}{c}0.000023 \\
(0.15)\end{array}$ \\
\hline BTM & $\begin{array}{c}-0.00080 \\
(-1.13)\end{array}$ & $\begin{array}{c}-0.00087 \\
(-1.22)\end{array}$ & $\begin{array}{c}0.00059 \text { * } \\
(1.74)\end{array}$ & $\begin{array}{c}0.00035 \\
(1.09)\end{array}$ \\
\hline Industry fixed effects & Yes & Yes & Yes & Yes \\
\hline Country fixed effects & Yes & Yes & Yes & Yes \\
\hline Observations & 2589 & 2589 & 2587 & 2587 \\
\hline Adjusted $R^{2}$ & 0.6401 & 0.4917 & 0.5837 & 0.5704 \\
\hline
\end{tabular}

This table provides the results of cross-sectional regressions for the COVID-19 period and the post-COVID-19 period. The dependent variable is defined as the volatility of the (abnormal) returns during the respective period. All variables are as defined in Table 1 . Industry and country fixed effects are included in all specifications and heteroscedasticity-robust standard errors are estimated. T-statistics are provided in parentheses. ${ }^{* * *},{ }^{* *}$, and ${ }^{*}$ indicate significance at the $1 \%, 5 \%$, and $10 \%$ level, respectively.

For our last analysis, we repeat the regressions of Table 4 with risk measures as dependent variables. When focusing on emitter groups, we find important differences between high and low emitters (see Table 7). Returns of high emitters are significantly 
more volatile than low emitters irrespective of the time period in question. For example, high emitters faced a $0.24 \%$ higher idiosyncratic volatility than low emitters during the COVID-19 period (column (2)). In the post-COVID-19 period, this effect decreased to $0.18 \%$ but remained significant. These results emphasize that extremely carbon-intensive stocks have to suffer from higher risk exposures than low-carbon stocks. Even during the crisis period, high emitters prove to be relatively riskier than their cleaner counterparts. This is in line with our argumentation that high emitters face high climate risks due to stranded assets and climate policy uncertainty.

Table 7. Influence of carbon intensity quartiles on risk during and after the COVID-19 period.

\begin{tabular}{|c|c|c|c|c|}
\hline & \multicolumn{2}{|c|}{ COVID-19 } & \multicolumn{2}{|c|}{ Post-COVID-19 } \\
\hline & (1) & (2) & (3) & (4) \\
\hline & Volatility & Idio. Volatility & Volatility & Idio. Volatility \\
\hline High Emitter & $\begin{array}{c}0.0017^{*} \\
(1.69)\end{array}$ & $\begin{array}{l}0.0024 \text { ** } \\
(2.27)\end{array}$ & $\begin{array}{c}0.0018^{* * *} \\
(3.50)\end{array}$ & $\begin{array}{c}0.0018^{* * *} \\
(3.80)\end{array}$ \\
\hline Medium Emitter & $\begin{array}{c}-0.00013 \\
(-0.15)\end{array}$ & $\begin{array}{c}0.00056 \\
(0.66)\end{array}$ & $\begin{array}{c}0.00075 \text { * } \\
(1.91)\end{array}$ & $\begin{array}{c}0.00077^{* *} \\
(2.05)\end{array}$ \\
\hline Lower Emitter & $\begin{array}{c}-0.00092 \\
(-1.14)\end{array}$ & $\begin{array}{c}-0.00044 \\
(-0.55)\end{array}$ & $\begin{array}{c}0.00032 \\
(0.86)\end{array}$ & $\begin{array}{c}0.00050 \\
(1.41)\end{array}$ \\
\hline Size & $\begin{array}{c}0.000089 \\
(0.37)\end{array}$ & $\begin{array}{c}-0.00081^{* * *} \\
(-3.33)\end{array}$ & $\begin{array}{c}-0.00073^{* * *} \\
(-6.31)\end{array}$ & $\begin{array}{c}-0.00096^{* * *} \\
(-8.80)\end{array}$ \\
\hline Debt & $\begin{array}{c}0.0075^{* * *} \\
(4.26)\end{array}$ & $\begin{array}{c}0.0085^{* * *} \\
(5.02)\end{array}$ & $\begin{array}{c}0.0029 * * * \\
(3.65)\end{array}$ & $\begin{array}{c}0.0030^{* * *} \\
(3.79)\end{array}$ \\
\hline Profitability & $\begin{array}{c}-0.013 * * * \\
(-4.25)\end{array}$ & $\begin{array}{c}-0.011^{* * *} \\
(-3.63)\end{array}$ & $\begin{array}{c}-0.011^{* * *} \\
(-7.57)\end{array}$ & $\begin{array}{c}-0.0094^{* * *} \\
(-7.03)\end{array}$ \\
\hline Cash Intensity & $\begin{array}{c}-0.0076^{*} \\
(-1.92)\end{array}$ & $\begin{array}{l}-0.0047 \\
(-1.23)\end{array}$ & $\begin{array}{l}-0.0015 \\
(-0.78)\end{array}$ & $\begin{array}{c}-0.00079 \\
(-0.44)\end{array}$ \\
\hline SGAE Intensity & $\begin{array}{c}-0.0071^{* *} \\
(-2.15)\end{array}$ & $\begin{array}{c}-0.0067^{* *} \\
(-2.11)\end{array}$ & $\begin{array}{l}0.0019 \\
(1.23)\end{array}$ & $\begin{array}{l}0.0015 \\
(1.00)\end{array}$ \\
\hline Historical Volatility & $\begin{array}{l}1.07^{* * *} \\
(17.66)\end{array}$ & $\begin{array}{l}1.24^{* * *} \\
(19.43)\end{array}$ & $\begin{array}{l}0.76^{* * *} \\
(25.73)\end{array}$ & $\begin{array}{l}0.77^{* * *} \\
(26.72)\end{array}$ \\
\hline Dividends & $\begin{array}{c}-0.00079 * * \\
(-2.26)\end{array}$ & $\begin{array}{c}-0.00059 * \\
(-1.69)\end{array}$ & $\begin{array}{c}0.000061 \\
(0.39)\end{array}$ & $\begin{array}{c}0.0000093 \\
(0.06)\end{array}$ \\
\hline BTM & $\begin{array}{c}-0.00100 \\
(-1.39)\end{array}$ & $\begin{array}{l}-0.0011 \\
(-1.53)\end{array}$ & $\begin{array}{c}0.00044 \\
(1.29)\end{array}$ & $\begin{array}{c}0.00020 \\
(0.60)\end{array}$ \\
\hline Industry fixed effects & Yes & Yes & Yes & Yes \\
\hline Country fixed effects & Yes & Yes & Yes & Yes \\
\hline Observations & 2589 & 2589 & 2587 & 2587 \\
\hline Adjusted $R^{2}$ & 0.6411 & 0.4934 & 0.5852 & 0.5725 \\
\hline
\end{tabular}

This table provides the results of cross-sectional regressions for the COVID-19 period and the post-COVID-19 period. The dependent variable is defined as the volatility of the (abnormal) returns during the respective period. We use dummy variables for carbon intensity quartiles. Control variables are as defined in Table 1. Industry and country fixed effects are included in all specifications and heteroscedasticity-robust standard errors are estimated. T-statistics are provided in parentheses. ${ }^{* * *}, * *$, and ${ }^{*}$ indicate significance at the $1 \%$, $5 \%$, and $10 \%$ level, respectively.

\section{Robustness Tests}

To ensure the validity of our results, we conducted several robustness tests. All results are available upon request from the authors. First, we enlarged the COVID-19 period and focused on the first quarter of 2020 as a crisis period. Thus, we take into consideration that the COVID-19 pandemic already started to spread as early as January 2020. In fact, the World Health Organization was first informed of cases of pneumonia of unknown cause in China on 31 December 2019 [46]. From this date on, events accelerated justifying the definition of a larger crisis period. The results for the first quarter 2020 are comparable to our more focused COVID-19 period. 
Second, we conducted the cross-sectional regressions of Equation (1) without fixed effects. For the difference-in-differences specification, we replaced the control variables for firm characteristics with firm fixed effects. All results remained stable.

Last, instead of relying on carbon intensity, we conducted all analyses based on absolute carbon emissions. Bolton and Kacperczyk [7] discover that the carbon premium is related to absolute emissions levels but not to carbon intensity. They justify their finding with the explanation that climate regulations target activities with high emissions levels. Taking absolute carbon emissions levels as our variable of interest does not alter our findings.

\section{Conclusions}

In recent years, climate risks have materialized as investment risks for financial assets [4]. Financial market participants are thus expected to incorporate this impending risk source in their stock valuation processes. We use the downturn of the stock market during the COVID-19 period in early 2020 as an exogenous shock to assess how far market participants incorporated carbon intensity (as measure for climate risk exposure) in their re-evaluation considerations of stocks during and after the crisis period or if they rather lost sight of the rising sustainable investment movement. The COVID-19 period constituted a time of heightened uncertainty and fear leading investors to re-evaluate their assets and preferences. It thus provides an opportunity to measure the impact of carbon intensity on stock returns and risk while holding carbon intensity levels constant. Furthermore, we analyze the subsequent recovery period to infer to what extent carbon intensity has established itself as a fundamental stock characteristic in stock analysis.

In the first descriptive analysis, high-emitting stocks had lower returns and higher risk measures during the COVID-19 period. In cross-sectional regressions, we found that carbon intensity had a significantly negative impact on returns and abnormal returns during the crisis period. This effect was more pronounced the higher the carbon intensity level was. Furthermore, carbon-intensive stocks gained significantly more in the post-COVID-19 recovery period compared to the precrisis period. Hence, they could make up for their additional losses incurred during the crisis period compared to low-emitting stocks.

Focusing on the risk perspective, carbon intensity did not have a significant effect in the COVID-19 period. Risk was rather driven by other firm characteristics such as debt and profitability. However, high emitters were still significantly riskier than low emitters. For the post-crisis period, the relationship between carbon intensity and risk turned significantly positive. Discussions on green economic stimulus packages and longterm risk exposures to stranded assets might have reinforced the riskiness of carbon-based assets. Higher risk and higher returns in the recovery period are also in line with the discussion on the existence of a carbon premium in stock markets [7]. Additionally, our findings complement the insights of environmental and social studies [28] as well as conclusions from financial-economic studies of the impact of COVID-19 on firm valuation (e.g., $[11,24])$.

Our results clearly show that market participants incorporate carbon intensity in their stock valuation considerations. More importantly, our results point to the assumption that high emitters are perceived as riskier and thus are more prone to being shunned by investors especially during times of high economic and societal uncertainty.

Our study faces two limitations. On the one hand, the data availability of carbon emissions is still insufficient and only to a certain extent consistent and reliable across databases (e.g., [47,48]). Furthermore, we make general global and cross-sectoral statements that may be even more pronounced and relevant in individual countries and industries. Future research can take this as a starting point and show the different influences of carbon risk and COVID-19 with the help of event studies and industry-specific assessment models. First indications of significant sectoral differences can be found in [40], for example. Further research questions arise from the separate inclusion of carbon pricing regimes as a possible amplifying driver of carbon risks. In addition, new analyses may also include 
further sector-specific analyses taking into account materiality (e.g., SASB materiality map) and the requirements of climate-related initiatives, e.g., EU taxonomy for sustainable activities as their core assessment criteria. The EU taxonomy also explicitly addresses the riskiness of non-sustainable activities: "The current COVID-19 pandemic has reinforced the need to redirect money towards sustainable projects in order to make our economies, businesses and societies - in particular health systems, more resilient against climate and environmental shocks" [49].

With our study, we reinforce the need to account for climate risks in investment decisions. Their integral assessment allows more profound risk management strategies, more accurate stock analyses with more precise forecasts and stock recommendations, and thus might impede huge losses in unforeseen crisis periods. With the COVID-19 pandemic, we had to learn that improbable risks can materialize quickly and have huge impacts on our portfolios. Hedging highly probable climate risks thus can turn out as a winning strategy to avoid a rude awakening in the future.

Author Contributions: Conceptualization, A.J. and M.N.; methodology, A.J. and M.N.; software, M.N.; validation, A.J. and M.N.; formal analysis, M.N.; investigation, M.N.; resources, A.J. and M.N.; data curation, M.N.; writing—original draft preparation, A.J.; writing-review and editing, A.J. and M.N.; visualization, A.J. and M.N.; supervision, M.N.; project administration, M.N.; funding acquisition, A.J. and M.N. All authors have read and agreed to the published version of the manuscript.

Funding: This research was funded by the Stiftung Mercator under Grant number 19026202. Andrea Jacob received financial funding as a scholarship holder of the Studienstiftung des Deutschen Volkes.

Institutional Review Board Statement: Not applicable.

Informed Consent Statement: Not applicable.

Data Availability Statement: No new data were created or analyzed in this study. Data sharing is not applicable to this article.

Conflicts of Interest: The authors declare no conflict of interest. The funders had no role in the design of the study; in the collection, analyses, or interpretation of data; in the writing of the manuscript, or in the decision to publish the results.

\section{References}

1. World Economic Forum. The Global Risks Report 2021, 16th ed.; Insight Report; World Economic Forum: Cologny, Switzerland, 2021; Available online: https://www3.weforum.org/docs/WEF_The_Global_Risks_Report_2021.pdf (accessed on 13 September 2021).

2. Mercure, J.-F.; Pollitt, H.; Viñales, J.E.; Edwards, N.R.; Holden, P.B.; Chewpreecha, U.; Salas, P.; Sognnaes, I.; Lam, A.; Knobloch, F. Macroeconomic impact of stranded fossil fuel assets. Nat. Clim. Chang. 2018, 8, 588-593. [CrossRef]

3. Amel-Zadeh, A.; Serafeim, G. Why and How Investors Use ESG Information: Evidence from a Global Survey. Financ. Anal. J. 2018, 74, 87-103. [CrossRef]

4. Fink, L. Larry Fink's 2021 Letter to CEOs. BlackRock. Available online: https://www.blackrock.com/corporate/investorrelations/larry-fink-ceo-letter (accessed on 13 September 2021).

5. Krueger, P.; Sautner, Z.; Starks, L.T. The Importance of Climate Risks for Institutional Investors. Rev. Financ. Stud. 2020, 33, 1067-1111. [CrossRef]

6. Fama, E.F. Efficient Capital Markets: A Review of Theory and Empirical Work. In Proceedings of the Twenty-Eighth Annual Meeting of the American Finance Association New York, New York, NY, USA, 28-30 December 1969; pp. $383-417$.

7. Bolton, P.; Kacperczyk, M. Do investors care about carbon risk? J. Financ. Econ. 2021, 142, 517-549. [CrossRef]

8. Andersson, M.; Bolton, P.; Samama, F. Hedging Climate Risk. Financ. Anal. J. 2016, 72, 13-32. [CrossRef]

9. de Jong, M.; Nguyen, A. Weathered for Climate Risk: A Bond Investment Proposition. Financ. Anal. J. 2016, 72, 34-39. [CrossRef]

10. Litterman, R. Pricing Climate Change Risk Appropriately. Financ. Anal. J. 2011, 67, 4-10. [CrossRef]

11. Zhang, D.; Hu, M.; Ji, Q. Financial markets under the global pandemic of COVID-19. Financ. Res. Lett. 2020, 36, 101528. [CrossRef]

12. Shehzad, K.; Xiaoxing, L.; Kazouz, H. COVID-19's disasters are perilous than Global Financial Crisis: A rumor or fact? Financ. Res. Lett. 2020, 36, 101669. [CrossRef]

13. Lyócsa, Š.; Baumöhl, E.; Výrost, T.; Molnár, P. Fear of the coronavirus and the stock markets. Financ. Res. Lett. 2020, $36,101735$. [CrossRef]

14. Ashraf, B.N. Stock markets' reaction to Covid-19: Moderating role of national culture. Financ. Res. Lett. 2021, $41,101857$. [CrossRef] 
15. Matsumura, E.M.; Prakash, R.; Vera-Muñoz, S.C. Firm-Value Effects of Carbon Emissions and Carbon Disclosures. Account. Rev. 2014, 89, 695-724. [CrossRef]

16. Chava, S. Environmental Externalities and Cost of Capital. Manag. Sci. 2014, 60, 2223-2247. [CrossRef]

17. Delmas, M.A.; Nairn-Birch, N.; Lim, J. Dynamics of Environmental and Financial Performance: The Case of Greenhouse Gas Emissions. Organ Environ. 2015, 28, 374-393. [CrossRef]

18. Busch, T.; Bassen, A.; Lewandowski, S.; Sump, F. Corporate Carbon and Financial Performance Revisited. Organ. Environ. 2020, 1-18. [CrossRef]

19. Hsu, P.-H.; Li, K.; Tsou, C.-Y. The Pollution Premium. Working Paper. April 2020. Available online: https://papers.ssrn.com/sol3 / papers.cfm?abstract_id=3578215 (accessed on 13 September 2021).

20. Ilhan, E.; Sautner, Z.; Vilkov, G. Carbon Tail Risk. Rev. Financ. Stud. 2021, 34, 1540-1571. [CrossRef]

21. Pástor, L'.; Stambaugh, R.F.; Taylor, L.A. Sustainable investing in equilibrium. J. Financ. Econ. 2021, 142, 550-571. [CrossRef]

22. Pedersen, L.H.; Fitzgibbons, S.; Pomorski, L. Responsible investing: The ESG-efficient frontier. J. Financ. Econ. 2021, $142,572-597$. [CrossRef]

23. Duchin, R.; Ozbas, O.; Sensoy, B.A. Costly external finance, corporate investment, and the subprime mortgage credit crisis. J. Financ. Econ. 2010, 97, 418-435. [CrossRef]

24. Ramelli, S.; Wagner, A.F. Feverish Stock Price Reactions to COVID-19. Rev. Corp. Financ. Stud. 2020, 9, 622-655. [CrossRef]

25. Shields, R.; El Zein, S.A.; Brunet, N.V. An Analysis on the NASDAQ's Potential for Sustainable Investment Practices during the Financial Shock from COVID-19. Sustainability 2021, 13, 3748. [CrossRef]

26. Lins, K.V.; Servaes, H.; Tamayo, A. Social Capital, Trust, and Firm Performance: The Value of Corporate Social Responsibility during the Financial Crisis. J. Financ. 2017, 72, 1785-1824. [CrossRef]

27. Engelhardt, N.; Ekkenga, J.; Posch, P. ESG Ratings and Stock Performance during the COVID-19 Crisis. Sustainability 2021, 13, 7133. [CrossRef]

28. Albuquerque, R.; Koskinen, Y.; Yang, S.; Zhang, C. Resiliency of Environmental and Social Stocks: An Analysis of the Exogenous COVID-19 Market Crash. Rev. Corp. Financ. Stud. 2020, 9, 593-621. [CrossRef]

29. Ramelli, S.; Ossola, E.; Rancan, M. Stock price effects of climate activism: Evidence from the first global climate strike. J. Corp. Financ. 2021, 69, 102018. [CrossRef]

30. Ramelli, S.; Wagner, A.F.; Zeckhauser, R.J.; Ziegler, A. Investor Rewards to Climate Responsibility: Stock-Price Responses to the Opposite Shocks of the 2016 and 2020 U.S. Elections. Rev. Corp. Financ. Stud. 2021, cfab010. [CrossRef]

31. Broadstock, D.C.; Chan, K.; Cheng, L.T.; Wang, X. The role of ESG performance during times of financial crisis: Evidence from COVID-19 in China. Financ. Res. Lett. 2021, 38, 101716. [CrossRef]

32. Pástor, L'.; Vorsatz, M.B. Mutual Fund Performance and Flows during the COVID-19 Crisis. Rev. Asset Pricing Stud. 2020, 10, 791-833. [CrossRef]

33. Hartzmark, S.M.; Sussman, A.B. Do Investors Value Sustainability? A Natural Experiment Examining Ranking and Fund Flows. J. Financ. 2019, 74, 2789-2837. [CrossRef]

34. Riedl, A.; Smeets, P. Why Do Investors Hold Socially Responsible Mutual Funds? J. Financ. 2017, 72, 2505-2550. [CrossRef]

35. Bouslah, K.; Kryzanowski, L.; M'Zali, B. Social Performance and Firm Risk: Impact of the Financial Crisis. J. Bus. Ethic 2018, 149, 643-669. [CrossRef] [PubMed]

36. Balcilar, M.; Demirer, R.; Gupta, R. Do Sustainable Stocks Offer Diversification Benefits for Conventional Portfolios? An Empirical Analysis of Risk Spillovers and Dynamic Correlations. Sustainablity 2017, 9, 1799. [CrossRef]

37. Nofsinger, J.; Varma, A. Socially responsible funds and market crises. J. Bank. Financ. 2014, 48, 180-193. [CrossRef]

38. TCFD. Implementing the Recommendations of the Task Force on Climate-related Financial Disclosures. Available online: https: / /assets.bbhub.io/company/sites/60/2020/10/FINAL-TCFD-Annex-Amended-121517.pdf (accessed on 13 September 2021).

39. Wan, D.; Xue, R.; Linnenluecke, M.; Tian, J.; Shan, Y. The impact of investor attention during COVID-19 on investment in clean energy versus fossil fuel firms. Financ. Res. Lett. 2021, in press. [CrossRef]

40. Mukanjari, S.; Sterner, T. Charting a "Green Path" for Recovery from COVID-19. Environ. Resour. Econ. 2020, 76, 825-853. [CrossRef]

41. Daniel, K.; Titman, S. Evidence on the Characteristics of Cross Sectional Variation in Stock Returns. J. Financ. 1997, 52, 1-33. [CrossRef]

42. Mazur, M.; Dang, M.; Vega, M. COVID-19 and the March 2020 stock market crash. Evidence from S\&P1500. Financ. Res. Lett. 2020, 38, 101690. [CrossRef]

43. Andrijevic, M.; Schleussner, C.-F.; Gidden, M.J.; Mccollum, D.L.; Rogelj, J. COVID-19 recovery funds dwarf clean energy investment needs. Science 2020, 370, 298-300. [CrossRef]

44. Shan, Y.; Ou, J.; Wang, D.; Zeng, Z.; Zhang, S.; Guan, D.; Hubacek, K. Impacts of COVID-19 and fiscal stimuli on global emissions and the Paris Agreement. Nat. Clim. Chang. 2021, 11, 200-206. [CrossRef]

45. Energy Policy Tracker. G20 Countries. Available online: https://www.energypolicytracker.org/region/g20/ (accessed on 13 September 2021).

46. World Health Organization. Pneumonia of Unknown Cause-China. Available online: https://www.who.int/csr/don/05 -january-2020-pneumonia-of-unkown-cause-china/en/ (accessed on 31 August 2020).

47. Busch, T.; Johnson, M.; Pioch, T. Corporate carbon performance data: Quo vadis? J. Ind. Ecol. 2020, in press. [CrossRef] 
48. Kalesnik, V.; Wilkens, M.; Zink, J. Green Data or Greenwashing? Do Corporate Carbon Emissions Data Enable Investors to Mitigate Climate Change? Working Paper 2020. November 2020. Available online: https:/ / ssrn.com/abstract=3722973 (accessed on 21 October 2021).

49. European Commission. EU taxonomy for sustainable activities. Available online: https://ec.europa.eu/info/business-economyeuro/banking-and-finance/sustainable-finance/eu-taxonomy-sustainable-activities_en (accessed on 13 September 2021). 